\title{
Corpus callosum lipoma
}

\section{Figure Brain MRI}

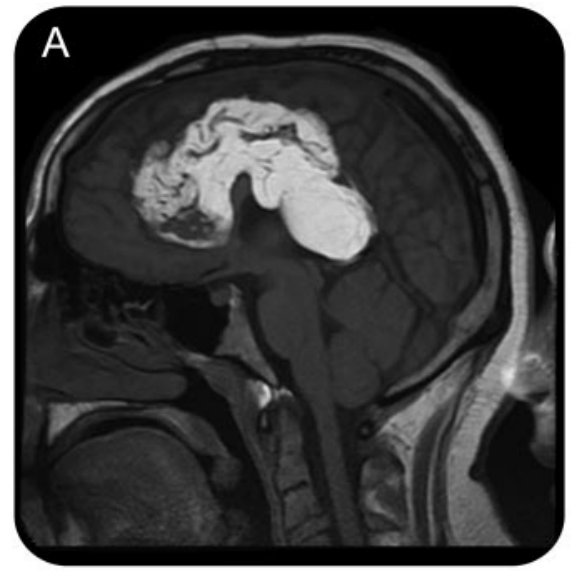

Sagittal T1 brain MRI

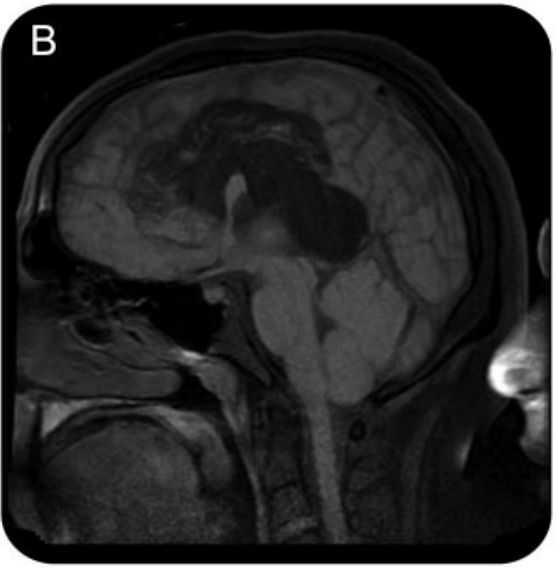

Sagittal fat saturation brain MRI

A large corpus callosum lipoma seen as a nonenhancing, homogeneous T1 hyperintensity (A) with signal attenuation on fat suppression images (B). There is associated severe dysgenesis of the corpus callosum.

A 24-year-old man was referred for uncontrolled generalized tonic-clonic seizures since childhood. Physical examination was unremarkable. Brain MRI revealed a large corpus callosum lipoma (CCL) and severe dysgenesis of the corpus callosum (figure). CCLs are not true neoplasms but congenital abnormalities, often found incidentally on imaging. A total of $50 \%$ of patients with CCL have epilepsy ${ }^{1}$; however, epilepsy is attributable to the CCL in only $20 \% .^{2}$ Surgical resection does not offer better seizure control and is associated with high perioperative mortality. With titration of oxcarbazepine and topiramate, this patient's seizure frequency has decreased to 2 per year.

Deepa S. Rajan, MBBS, MD, Alexandra Popescu, MD, Pittsburgh, PA

Author contributions: Dr. Rajan: drafting/revising the manuscript. Dr. Popescu: drafting/revising the manuscript.

The authors report no disclosures relevant to the manuscript. Go to Neurology.org for full disclosures.

Correspondence \& reprint requests to Dr. Rajan: rajands@upmc.edu

1. Jabot G, Stoquart-Elsankari S, Saliou G, Toussaint P, Deramond H, Lehmann P. Intracranial lipomas: clinical appearances on neuroimaging and clinical significance. J Neurol 2009;256:851-855.

2. Loddenkemper T, Morris HH, Diehl B, Lachhwani DK. Intracranial lipomas and epilepsy. J Neurol 2006;253:590-593. 


\section{Neurology}

Corpus callosum lipoma

Deepa S. Rajan and Alexandra Popescu

Neurology 2012;78;1366

DOI 10.1212/WNL.0b013e318251838b

This information is current as of April 23, 2012

\section{Updated Information \&} Services

References

Citations

Subspecialty Collections

Permissions \& Licensing

Reprints including high resolution figures, can be found at: http://n.neurology.org/content/78/17/1366.full

This article cites 2 articles, 0 of which you can access for free at: http://n.neurology.org/content/78/17/1366.full\#ref-list-1

This article has been cited by 1 HighWire-hosted articles: http://n.neurology.org/content/78/17/1366.full\#\#otherarticles

This article, along with others on similar topics, appears in the following collection(s):

All Clinical Neurology

http://n.neurology.org/cgi/collection/all_clinical_neurology

All Epilepsy/Seizures

http://n.neurology.org/cgi/collection/all_epilepsy_seizures

All Imaging

http://n.neurology.org/cgi/collection/all_imaging

MRI

http://n.neurology.org/cgi/collection/mri

Information about reproducing this article in parts (figures,tables) or in its entirety can be found online at:

http://www.neurology.org/about/about_the_journal\#permissions

Information about ordering reprints can be found online:

http://n.neurology.org/subscribers/advertise

Neurology ${ }^{\circledR}$ is the official journal of the American Academy of Neurology. Published continuously since 1951, it is now a weekly with 48 issues per year. Copyright Copyright () 2012 by AAN Enterprises, Inc.. All rights reserved. Print ISSN: 0028-3878. Online ISSN: 1526-632X.

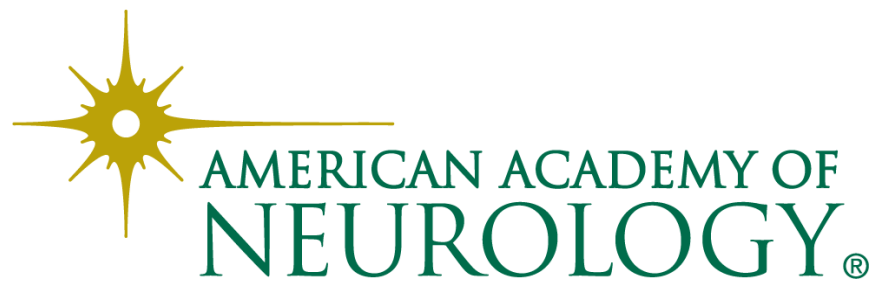

